\title{
Creating Desire for 'Undesirables' by subverting Means-End Chain
}

\author{
Kriti Chadha ${ }^{1}$ and Harsh V. Verma ${ }^{2 *}$ \\ 'PhD Research Scholar, Faculty of Management Studies, University of Delhi, Delhi - 110007, \\ India; kritichadha.Isr@gmail.com \\ 2Professor, Faculty of Management Studies, University of Delhi, Delhi - 110007, India; harshverma@fms.edu
}

\begin{abstract}
Purpose and meaning have always been fundamental to human and human institutions. In current times, "purpose" is actively researched by academic scholars and practiced by businesses. Purpose and values supersede product features or price in forming deeper connections with consumers by targeting emotional triggers. This paper, with its focus on alcohol beverage industry, studies how these brands target the innate need of humans to reach their terminal values or higher-order purpose in life to sell their products, consumption of which is associated with both health and social issues. Analysis of the selected alcohol beverage advertisements shows how marketers cleverly shift attention from the product attributes to consumers' values, thus skipping the steps of Means-End chain. These personal values help in the attainment of one's purpose (the reason for existence beyond oneself) ensuring satisfaction and contentment at an emotional level. In a category where brand preference is key, people's motivation for selecting a particular brand they drink might be closely related to the underlying personal values.
\end{abstract}

Keywords: Means-End Chain, Values, Purpose, Alcohol Beverage

JEL classification: M31, M37

\section{Introduction}

According to Statistics MRC, the Global Alcoholic beverages market accounted for $\$ 1324.1$ billion in 2017 and is expected to reach $\$ 1864.2$ billion by 2026 , making it a commercially lucrative market ${ }^{1}$. The consumption of alcohol is mostly justified on the grounds of occasional drinking, fun, relaxation during social gatherings despite being associated with both health and social issues. Its health consequences include liver malfunctioning, high risk of injury-especially from drunk driving, high risk of addiction, anxiety, etc whereas social consequences range from financial distress due to excessive drinking to humiliating drinking incidents like vomiting, passing out, violence etc.

This study aims to analyse how higher-order purpose and values are used as a launchpad to sell products with adverse health and social consequences. It throws light on how some brands (alcohol brands in this study) digress from real the Means-End chain (MEC) and try to appeal the psyche of the consumer or connect with them at a higher level, through contrived and false connections.

Sheth ${ }^{2}$ suggested that to be comprehensive in marketing products, both researchers and management have to adopt a consumer-based orientation rather than one that merely focuses on product characteristics. The consumer orientation of marketing emphasizes the satisfaction of real needs of consumers. A consumer may buy the product for its functional need satisfaction but what is the higher motivating force to choose one brand over others is purely emotional and can be understood through MEC. Marketers use Means-End analysis to understand the deep motivations of purchase decisions by studying consumer cognitive processes.

The first contributions to the theoretical foundation of the Means-End theory came from the psychology and economics fields and have always intended to demonstrate

*Author for correspondence 
that consumers buy products not simply because of intrinsic attributes but because of contents that stimulate their cognitive structure ${ }^{3}$. The Means-End theory aims at identifying the links between consumer behaviours and values, explaining how the choice of a good or service serves the achievement of the desired condition (Reynolds \& Gutman; Grunert \& Grunert) $)^{4,5}$. Means are objects (products) or activities in which people engage (running, reading), Ends are valued states of being such as happiness, security, accomplishment. Thus, a Means-End chain can be summed as a model that seeks to explain how a product or service selection facilitates the achievement of desired end states.

The paper proceeds as follows: Section 2 explicitly states the research objectives and its implications. Section 3 reviews the previous work on the Means-End chain and also discusses its components (attributes, consequences and values). How values are connected to attributes, behaviour and motivation are discussed in Section 4 . Section 5 elaborates the concept of purpose and why it is important and also how marketers are trying to deviate from the Means-End chain and trying to sell undesirable products. Section 6 describes the methodology, explaining how data for analysis was selected and also how connotative meanings are derived from lexical meaning to target the values or higher order purpose of consumers. The next Section deals with the ad analysis for the selected alcohol beverage brands discussing how they use their purpose statements, taglines etc to connect with higher order needs of consumers, followed by conclusion in Section 8 .

\section{Research Objectives and Implications}

The principle aim of this paper is to explore how alcohol beverage brands are digressing from the Means-End chain and appealing to higher order purpose/values to sell their products, which are not beneficial from both health and social perspective. This research paper broadly answers three questions:

1. Explore the concept of purpose and values and its relationship with consumer motivation.

2. Theoretically explore the linkages between purpose and values and consumer brand preference.

3. Describe and interpret with selected alcohol brand ads - how they digress from regular MEC and derive connotative meaning from lexical meanings.
This study is important from the social perspective as the consumers will be well informed how marketers are trying to sell them undesirables/products with no functional consequences by digressing and making contrived relations. The marketers are appealing the emotional needs of people by relating to purpose and values which, as proposed in the theory is the ultimate aim of the consumers to reach. This study aims to warn the consumers about the appropriation of ethical and progressive values as a form of advertising just to make more profit while hiding the dark side of conventional capitalistic business management practised by many brands (in this study - alcohol brands).

Deeper motivations of humans that trigger positive behaviour like values and higher order purpose are used as launch pad to sell product that have both health and social consequences. Marketers are commodifying values and purpose in order to beat competition and forming deeper bonds with its consumer base.

The study is also important for marketers as it proves that values and purpose are important for consumers and thus having one for their brand or organization might be a necessity to succeed.

\section{Means-End Chain Model \& its Components}

The Means-End chain model developed by Gutman ${ }^{6}$ theorizes "that values are dominant factors in the pattern of consumer purchase; that these consider products or services based on the function of satisfying values; that all actions have consequences (desired or not); and, finally, that there is a connection between consequences and product or service attributes. The central aspects of the model are consumer decision-making that produces desired consequences (positive) and minimizes undesired ones (negative)."

The MEC model is based on the attribute-consequencevalue (A-C-V) sequence (Gengler, Mulvey, \& Oglethorpe; Vriens \& Hofstede; Olson \& Reynolds) ${ }^{7.8 .9}$. It can be seen as a chain from product attributes (means) to the consequences of using the product to the consumer's values (ends). Figure 1 provides a graphical explanation of the MEC - attributes being the distinct characteristics of a product or service, consequences are defined as any result (physio-logical or psychological accruing directly or indirectly to the consumer and can be both desirable and undesirable) and lastly, 


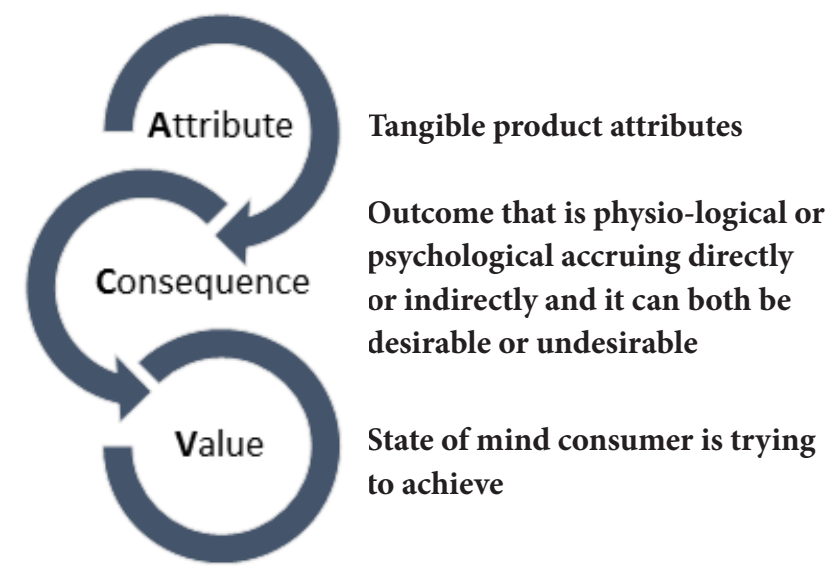

Figure 1. Means-End Chain.

values are centrally held cognitive elements that trigger motivation for behaviour ${ }^{10}$.

\subsection{Values}

Value has been a key concept in the social sciences and has played an important role not only in sociology, but in psychology, anthropology, and related disciplines. Values are used to characterize cultural groups, societies and individuals, and to explain the motivational bases of attitudes and behaviour. In marketing, values research has been of particular interest in the area of consumer behaviour (Vinson, Scott \& Lamont; De Mooij) $)^{10,11}$. Consumer behaviour includes an examination of the range of customers' needs, attitudes, and motivation to purchase (Borden) $\frac{12}{}$.

To say that a person 'has a value' is to say that "he has an enduring belief that a specific mode of conduct or endstate of existence is personally and socially preferable to alternative modes of conduct or end-states of existence" (Rokeach) ${ }^{13}$. These end-states give expression to human needs; thus, it can be said that values provide the goals toward which behaviour is motivated.

Rokeach ${ }^{14}$ argued that values are taught at an early age and he assumed that the total number of values a person possesses is relatively small and that all people everywhere possess the same values to different degrees and that the antecedents of human values can be traced to culture, society and its institutions. While we come from different backgrounds and cultures, our values are what we have in common. He categorized values into 2 heads:
- Terminal values: are defined as the end states of existence towards which people strive (e.g. world peace, pleasure, happiness, true friendship) and

- Instrumental values: are defined as an act of "doing" rather than "being". These can be summed as preferable modes of behaviour or means of achieving the terminal values. (e.g. open-mindedness, honesty, forgiving).

Similarly, Schwartz's value theory ${ }^{15,16}$ specifies 6 features of values:

- Values are beliefs linked to affect

- Values refer to desirable goals that motivate action

- Values transcend specific actions and situations

- Values serve as standards or criteria serving as a guide for selection or evaluation of actions, policies, people, and events

- Values are ordered by importance relative to one another

- The relative importance of multiple values guides action implying any attitude or behaviour typically has implications for more than one value.

\subsection{Attributes and Consequences}

Attributes can be categorised into Intrinsic and Extrinsic. Intrinsic attributes relate to the function of a product (such as the design, performance, shape, components, and size). To change the intrinsic attributes would mean altering the product. Extrinsic benefits are the meaning or emotional attachment of the product (such as value, image) - perceptions a user has $\frac{17,18}{}$.

But when a consumer decides to buy a product, the decision is not only dependent upon selecting the attribute desired in the product per se but, also on the perceived consequences of product use. If the consumer perceives that the product is a means to some important consequences which themselves will lead to the satisfaction of particular values, he will buy the product in order to reach the end state desired. In this way the goal of a Means-End chain becomes to link presumably concrete product attributes with the consequences of those attributes and, in turn, to link consequences with consumers' values or desired end-states (Gutman; Olson \& Reynolds; Vinson, Scott \& Lamont) 


\section{Relating Values to Attitude and Behaviour and Motivation}

Clawson \& Vinson ${ }^{20}$ suggested that values may prove to be one of the most powerful explanations of, and influences on, consumer behaviour. They can perhaps equal or surpass the contributions of other major constructs including attitudes, product attributes, product classifications and lifestyles. Thus, knowledge of values and its relation with attitude and behaviour is imperative before further study.

Attitude can be defined as an expression of how we feel about any given thing, situation or object and it is the reflection of the values we hold. Rosenberg and Hovland ${ }^{21}$ gave $\mathrm{ABC}$ model determining the components of attitude:

- Affective - part of attitudes that drives a person's feelings or one's emotional response

- Behavioural - refers to the behaviour a person displays or how one actually reacts in accordance to their attitude in a particular situation.

- Cognitive - refers to a person's opinion, beliefs or thought about a subject matter or a person.

Pitts \& Woodside ${ }^{22}$ reported a positive relationship between values and attitude. Attitude can also be defined as a judgment made on the 'attitude object' (a person, place, task, event, skill, etc.). Judgments from attitude can range from positive, negative or neutral. A positive attitude is needed in an individual in order for him/her to be motivated and engaged in a task.

When relating the MEC approach to the concept of human motivation, the literature interprets the linked elements which comprise the Means-End chains as representations of peoples' underlying motivation (Claeys et al. $)^{23}$. Providing the rationale for this interpretation, Reynolds, and Gutman ${ }^{24}$ points out that an understanding of the structure of attributes, consequences, and values depicted in Means-End chains facilitates a 'motivational perspective' because it uncovers the underlying reasons why certain attributes or expected consequences are desired.

Behaviour is another relevant term and can be defined as "anything an organism does" or "what an organism does" (Davis; Lehner; Pierce \& Cheney) $25,26,27$. To put it simply behaviour is a way in which one acts or conducts itself, mostly towards others. Feather ${ }^{28}$ suggests that values affect behaviour by influencing one's evaluation of the possible consequences of his or her actions. Other researches proposing influence of values on subsequent behaviour include William ${ }^{29}$ and Carman ${ }^{30}$.

Research indicates that attitude can cause an individual to change his or her behavioural intention and possess a consistently unfavourable or favourable response to a particular object (Ajzen; Bagozzi \& Warshaw) ${ }^{31,32}$. Hansen ${ }^{33}$ contends that if an individual's attitude toward an object is favourable, he or she is more likely to engage in positive behaviour toward the object.

Linking the concepts of value, attitude, and behaviour, leads to V-A-B theory by Homer \& Kahle ${ }^{34}$ who proposed hierarchal association of the three terms in context of natural food shopping. Shim \& Eastlick ${ }^{35}$ examined the relative importance of values and its influence on attitude and behaviour in context of mall shopping. To sum up we can say that Attitudes arise out of core values that provide motivation to engage in any task thus leading to behaviour or action as shown in Figure 2.

\subsection{Purpose}

Values are said to give individuals a sense of purpose. Purpose, the latest buzz word in marketing basically answers the ultimate question of "WHY". The lexical definition states purpose as a reason for which something is done or created or in other words its reason for existence.

Since times immemorial Purpose has had a strong connection with people's life. Victor Frankl's ${ }^{36}$

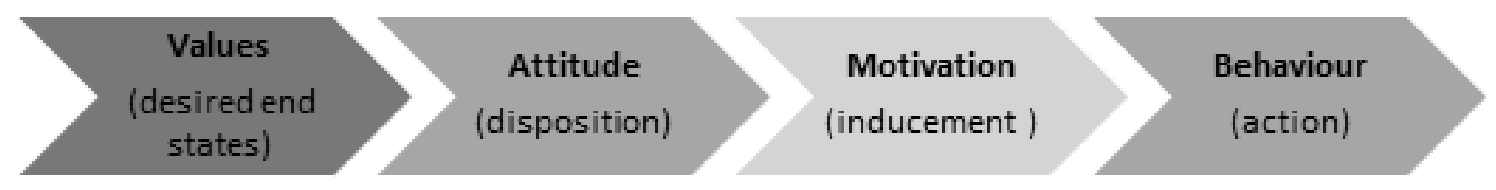

Figure 2. Relationship between Values, Attitude, Motivation \& Behaviour. 
research showed that purpose is highly conducive to well-being: he emphasized the role of finding meaning and purpose as human's most important quest and gracious gift for addressing psychological difficulties. Purpose is also said to positively influence physiological well-being and has repeatedly been linked to longevity. Krause ${ }^{37}$; Sone and colleagues ${ }^{38}$ etc all found that older adults who reported a higher sense of purpose in life experienced a significantly diminished risk of mortality over time.

The concept of purpose also extended to organizations giving purposeful organizations an edge over competitors. A strong sense of purpose positively impacts performance through various mechanisms. Firstly, purpose serves as the North Star giving organizations a sense of direction. It is great for employee engagement, job satisfaction, attracting and retaining talent. The 2016 Workforce Purpose Index by Imperative \& LinkedIn ${ }^{39}$ reported that $73 \%$ of employees in businesses with a clear brand purpose are satisfied. Having a purpose ensures the acquisition of a committed workforce and retention of the best talent. Deloitte millennial survey $2016^{40}$ showed that "Millennials prioritized the sense of purpose around people rather than growth or profit maximization".

Research from the E.Y. Beacon Institute and Harvard Business School ${ }^{41}$ also shows that companies that lead with purpose are more likely to be profitable; $85 \%$ of purpose-led companies have shown positive growth in the past three years, with $58 \%$ growing by more than $10 \%$, thus implying better financials for purpose-driven organizations. So, purpose is not just a lofty ideal; it has practical implications and by tapping into that power, one can transform an entire organization.

Recent trends have seen a move towards adopting a strategy of purpose not only among organizations but brands too. The concept of purpose including values has gained importance as fighting over product features and price has become passé. When choosing brands, today's consumers care more about what kind of impact brands are making in the world than just what products or services they offer. The traditional approach in branding and advertising often focused on product attributes and basic benefits but failed to dig deeper into the psyche of consumers to determine the emotional triggers that actually drive their behaviour and action. Millward Brown's BrandZ research $\mathrm{f}$ or WPP ${ }^{42}$ over the past 10 years provides convincing data to prove that brand purpose drives value (brand equity). Purpose enables to form authentic emotional connections with those consumers who share the same essential values and enhance their brand loyalty, increase brand equity and thereby increasing its long-run profitability.

\subsection{How do Marketers Sell Undesirable/ Unhealthy Products? - Deviation from MEC}

As discussed earlier, drinking represents both a multibillion-dollar industry and a major domain of leisure activity in contemporary society, making it important for marketers to know how to reach out to their consumers. In a category where brand preference is key, people's motivation for selecting a particular brand they drink might be closely related to the underlying personal values and our study aims to find that.

Many studies have highlighted that food products contain abstract attributes directly connected to the value system of individuals who buy goods not only for the intrinsic characteristics of the goods but also for the benefits the goods can produce in accordance with the individuals' values. Finch ${ }^{43}$ examined customers' behaviour with respect to purchasing organic food products.

Values are imperative for humans as they affect attitude, motivation, preference, behaviour, etc. Thus, the MEC model by alcohol beverage brands seems to offer an interesting new direction for understanding how consumers are motivated to buy in this market by shifting the attention from the attribute level to the value level.

Figure 1 shows the regular Means-End chain which links attributes of products (which in this industry could be alcohol content, product quality, smoothness) with particular consequences (direct consequences- health consequences coupled with some social issues like drunk driving \& indirect consequences as joy, fun, etc), and how these consequences satisfy their personal values (like sense of accomplishment, equality, friendship, etc).

Alcohol beverage brands cleverly skip the second level in the chain and try to connect directly to the end state (value state) as shown in figure 3. This is done because the product offered is undesirable and has negative consequences from both health and social perspective. By linking directly with the value state, brands motivate the consumers to buy their product in comparison to that of the competitor so as to achieve the desired end state. Here the competition moves away from the basic intrinsic attributes to extrinsic and more abstract attributes which are the unique value proposition of each brand. 


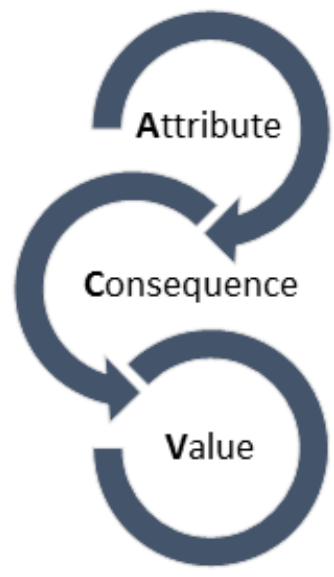

Figure 1. Means-End Chain.

\section{Methodology}

This qualitative study involves both exploratory research and descriptive research. The study aims to explore the relevance of values and purpose in brand selection of alcohol beverages and it also describes how marketers are tapping this innate need of humans to reach to terminal values and higher order purpose to sell their undesirable products. As mentioned earlier many studies have used MEC to explain consumers motivation in drinking and also their brand preference (McDonald, Wagner \& Minor; Judica \& Perkins; Fabbrizzi, Marinelli, Menghini \& Casini) ${ }^{44,45,3}$. Since the relation of purpose and values as a concept, is in its nascent stages, therefore this study adopts a discovery-oriented (Mahrer ; Mahrer \& Boulet) ${ }^{46,47}$ approach to studying this phenomenon used by alcohol beverage brands. The discovery-oriented approach is used so as to describe the current situation: values and purpose as an important differentiating factor for brands and also discover the digression of alcohol brands from real MEC to a contrived one. Unlike other research that start with hypothesis testing, a discovery -oriented research starts with questions. Ads selected for this study were video ads ( $\mathrm{Tv}$, internet or any social media platform). Also, Ad campaigns across regions were taken into consideration however the brands selected were the ones consumed in the Indian market. The data for choosing the brands were taken from Statista reports of 2016 to 2019 and the chosen brands were the highest contributor in their respective fields. The visual as well as verbal content of the ads were analysed and interpreted. The interpretation involved finding lexical meanings and synonyms (using thesaurus) ${ }^{48}$ and then deriving/

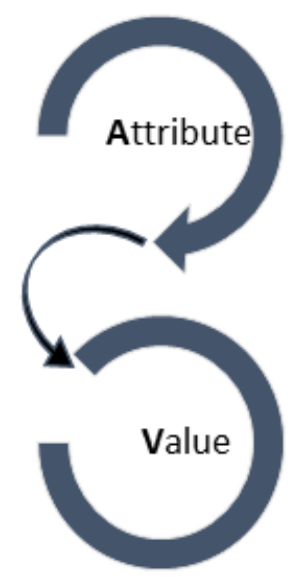

Figure 3. Shortcoming in MEC by Alcohol Beverage Brand.

interpreting connotative meaning using visual and verbal components of the ad.

\subsection{Data Selection}

Alcoholic beverages can usually be divided into 3 parts: spirits, beer, and wine. Spirits as a category contributed to the maximum consumption percentage (statistics taken from Statista and source of the report is WHO data ${ }^{49}$ ). Within the category of spirits, whisky contributed to the maximum share in the Indian market (statistics taken from Statista and sources of the report are Live mint, Global Data, and Euromonitor ${ }^{50}$ ), thus whisky brands (either country produced or IMFL) were taken into consideration for the purpose of the study. Statistics taken from Statista and other sources of the report ${ }^{51}$ represents the companies that have the maximum market share of whiskey and thus brands from these companies were chosen. The selection criteria of brands were most valuable Indian brands 2019 - BrandZ report.

\subsection{Deriving Connotative Meaning to Reach Value State or Higher Order Purpose}

As mentioned earlier values are believed to have a substantial influence on the behaviour of individuals (Rokeach) $)^{14}$ and can also provide a powerful explanation of consumer behaviour (Clawson and Vinson) ${ }^{20}$. Ad analysis in the coming section shows the clever use of advertising in relating to values and higher-order purpose needs, how brands with their taglines or organizational purpose (extended in form of brand purpose) try to derive connotative meaning from their lexical meaning 
and connect to the users subconsciously (e.g.: Make it Large - both your life and drink size).

Meaning is an important component of language. Meaning or the information one wants to communicate can be conveyed through a number of means like gesture, picture, signals, etc. Semantics as a branch of linguistics is mainly concerned with how the 'meaning' is conveyed by the linguistics system consisting of different unit structures like sentence, phrases, words, morphemes, etc. Semantics is defined as "the study of meaning" by Lyons ${ }^{\underline{52}}$ and "study of meaning in language "by Hurford and Heasley ${ }^{53}$. Geoffrey Leech ${ }^{54}$ classified meaning into 7 types:

- Logical or conceptual meaning,

- Connotative meaning,

- Social meaning,

- Affective meaning,

- Reflected meaning,

- Collective meaning and

- Thematic meaning.

This study focuses on primarily two types of meaning: lexical or denotative and the other one being connotative.

Conceptual meaning also referred to as logical, cognitive or denotative meaning is based on two structural principles, which are contractiveness and constituent structures. It is usually derived from definitions found in dictionaries. While the conceptual meaning is more stable the connotative meaning is mostly shaped by culture, background, society, etc. It is relatively unstable or so to say it is subjective and open to multiple interpretations. While conceptual can be said to present in definition, connotative is implied or derived.

Ferdinand de Saussure $\mathrm{e}^{55}$ is regarded as the father of both linguistics and structuralism. He proposed that language is a system of signs, and that each sign is composed of two parts: a signifier which is a word, or sound-pattern and a signified which is the concept (1916 - Course in General Linguistics). Saussure stressed that the relationship between the signifier and the signified is conventional and arbitrary and that both terms are psychological in nature. There is no one-to-one relation between the signifier and the signified. For instance, the sound image "tree" may refer to different kinds of trees or it may even be a metaphor for a forest. Therefore, it is inferred that meaning is arbitrary and unstable. Similarly, Roland Barthes ${ }^{\frac{56}{}}$ adopted from Louis Hjelmslev ${ }^{57}$ the notion that there are different orders of signification. The first order of signification is that of denotation: at this level, there is a sign consisting of a signifier and a signified. Connotation is a second-order of signification which uses the denotative sign (signifier and signified) as its signifier and attaches to it an additional signified. In this framework connotation is a sign which derives from the signifier of a denotative sign (so denotation leads to a chain of connotations). What can be deduced is that the signifier or a signified depends entirely on the level at which the analysis operates: a signified on one level can become a signifier on another level $\frac{58}{}$. This is the mechanism by which signs may seem to signify one thing but are loaded with multiple meanings. The following section shows the use this framework of the derivation of connotative meaning from lexical for the purpose of ad analysis.

\section{Analysis}

The most acclaimed among the alcohol beverage brand is Johnnie Walker with its purpose statement "keep walking". The striding man of Johnnie Walker stands for progress, a value that every individual strives for. All their advertisements communicate the same message that moving (progressing) in life is very important. It's a fundamental human value to hope for a better tomorrow than today. Every movement or progression whether forward or backward will decide your next step or position in life. It motivates individuals to advance from the lowerlevel purpose i.e. achievement/success to a higher-order purpose i.e. Progress. In the keep walking advertisement, a robot is shown wishing to be like humans - to be able to love, feel, emote etc, telling that they might not be the future of this world despite this hype for artificial intelligence and machine learning as their only advantage of immortality (which they will achieve by not wearing out) can also be achieved by humans too by constantly evolving and progressing. In ads like 'dear brother' and 'keep walking the next step', the protagonist expresses the need to keep walking even if one can't run as any step is better than no step (stagnation). He claims that one can always define oneself by where one is headed instead of where one is standing. The success of the brand can be also be seen by how the brand ropes in various economies like Brazil, Lebanon, etc. The 'sleeping giant' campaign of Brazil (giant of Latin America) shows a rock giant waking from its slumber and making progress which was symbolic of the Brazilian economy making progress 
in terms of the stock market, GDP, etc. 'Keep walkingLebanon ad' was shown in the light of the Lebanese crisis to inspire citizens. The ad showed people coming together and solving problems together moving forward by combining their resources. What makes a brand iconic is when its steps beyond its category and means much more than just a product to its consumers. Johnny Walker skilfully appeals the psyche of the consumer by deriving connotative meaning of progress from literal meaning of walking (implies any movement forward). It inspires consumers to be progressive in all areas of life, opportunities etc, thus connecting the alcohol brand with the value of "progress" - a value that every individual stride for.

The brand under Pernod Ricard - Royal stag uses clever advertising or what can be said purpose washing to promote it as a brand that wants to Make It Large (both in terms of the drink size and also large in life). The lexical meaning of large is extensive, huge etc which is connotatively interpreted as going beyond the average or making a worthy contribution. The initial ads of Royal stag starring Shahrukh Khan views that every "small" step or contribution you make counts and all these small sums up to become that one large change in life (Small Milate jao, Large banate jao). The smart use of words small and large both with respect to drink size and attitude in life is a point worth noticing.

The analysis of the recent ad shows that Royal stag is connected with self-made individuals who have magnified the canvas of life and those that embody selfbelief. It relates itself to a larger than life attitude. It teaches individuals to self-evaluate themselves and consciously realize that there is a lot to achieve and that they should stand out and not settle to be part of the queue. This tagline connects to the higher-order purpose of humans to make it big in life which is also associated with the fifth need of Maslow: the need for self-actualization. The need for self-actualization involves "the desire to become more and more of what one is, to become everything that one is capable of becoming". Thus, it can be said that connection with purpose or the value of accomplishment seems to be contributing to the fulfilment of perhaps the highest order need according to Maslow, self-actualization. With their new royal stag cricketers' campaign - "Wanna make it Large - It starts with you" Royal Stag is positioning itself as an iconic brand inspiring young people to dream big, achieve big and in turn make it large, by creating their own identity by hard work.

The next analysis of Chivas advertisement shows Farhan Akhtar in a red-carpet event asking a few people to join while being photographed. He poses important questions like: "Are we going to succeed alone, or take people along" \& "Will we win the old way, or the right way?" The ad tries to promote that, in today's time of dwindling trust, winning is no longer about proving the world wrong, it's about getting together and making the world right. The concept of We is replacing the concept of I, Me, Myself.

The term chivalry is used to connect to true qualities of modern man: a code of conduct that sets him apart. 'Win the Right Way' campaign communicates Chivas Regal's brand values and aims to inspire a new generation to achieve success whilst making a positive impact on the lives of others. It also stands true to the brand's philosophy of "succeed as gentlemen"- how success is beyond material gains and is about enriching the lives of others. It emphasizes that true success lies less in its clichéd symbolism and more in its impact on the world. These values of uniqueness, rightness, bravery, unselfishness etc desired in men, is what the brand is trying to poach.

Even brands like McDowell's No.1 soda launched a campaign in 2014 called 'No1Yaari'. Yaari meaning 'friendship' is one value close to every human being. According to Maslow's need hierarchy "belongingness" is a basic human need and aspired by every individual. The ad also shows celebrating deep bonds of 'brotherhood' (extended friendship - or friends turning into an extended family). In this fast-moving life, older family structures (joint families, etc) are dismantling as young individuals have to move out of their homes for work or study. As they do so, they "start to find a new family in their friends. This feeling is easily relatable and more engaging because everybody has that inner circle of friends whom they rely on for moving their lives to a better and richer place. Previous campaigns were on similar lines of Friendship "yaaro se bane hum" - we are made / we are a part of our friends.

Table 1 shows how selected alcohol brands derive connotative meaning from lexical meaning, to sell products whose consumption is associated with both health and social risks. 
Table 1. Deriving Values/Higher Order Purpose: From Lexical Meaning to Connotative Meaning

\begin{tabular}{|c|c|c|c|c|c|c|}
\hline Brand & $\begin{array}{l}\text { Promoted } \\
\text { As }\end{array}$ & Lexical Meaning & Antonym & $\begin{array}{l}\text { Connotative Meaning } \\
\text { Derived from Lexical } \\
\text { Meaning }\end{array}$ & $\begin{array}{l}\text { Connotative } \\
\text { Meaning } \\
\text { (Antonym) }\end{array}$ & $\begin{array}{l}\text { Value Associated/ } \\
\text { Derived }\end{array}$ \\
\hline $\begin{array}{l}\text { JOHNNIE } \\
\text { WALKER }\end{array}$ & $\begin{array}{l}\text { Keep } \\
\text { Walking }\end{array}$ & $\begin{array}{l}\text { forward or onward } \\
\text { movement / advance } \\
\text { /gradual betterment } \\
\text { /improvement / } \\
\text { evolution /growth }\end{array}$ & $\begin{array}{l}\text { Backward movement / } \\
\text { downfall or decent/ } \\
\text { gradual deterioration / } \\
\text { decline/stagnation/ }\end{array}$ & $\begin{array}{l}\text { to move on in life / to } \\
\text { advance in life / to look } \\
\text { for growth / to never } \\
\text { give up / to broaden } \\
\text { your thinking horizons } \\
\text { and discover new } \\
\text { opportunities }\end{array}$ & $\begin{array}{l}\text { no change or } \\
\text { stagnation in } \\
\text { thoughts, work, } \\
\text { life etc/ pull back } \\
\text { all efforts after a } \\
\text { failure }\end{array}$ & Progress \\
\hline ROYAL STAG & $\begin{array}{l}\text { Its Your Life, } \\
\text { Make It } \\
\text { Large }\end{array}$ & \begin{tabular}{|l|} 
considerable/enormous \\
/ extensive / full/ \\
generous/ giant/ \\
grand/huge/ \\
immense/massive \\
sizable/vast
\end{tabular} & $\begin{array}{l}\text { cramped/limited/ } \\
\text { little/ minor / narrow / } \\
\text { small }\end{array}$ & \begin{tabular}{|l|} 
attitude to rise beyond \\
average or go beyond \\
normal or common/ \\
substantial \\
contribution towards \\
something or to make \\
it big in life / make \\
your life worthy
\end{tabular} & \begin{tabular}{|l|} 
to indulge in \\
things that are \\
insignificant or \\
unimportant / not \\
be stuck with \\
societal pressures \\
and clichés
\end{tabular} & $\begin{array}{l}\text { Sense of } \\
\text { accomplishment/ } \\
\text { Larger than life }\end{array}$ \\
\hline CHIVAS & $\begin{array}{l}\text { Live With } \\
\text { Chivalry }\end{array}$ & $\begin{array}{l}\text { qualities of ideal knight } \\
\text { gallant, courteous, } \\
\text { generous in behaviour } \\
\text { /polite, kind, and } \\
\text { unselfish behaviour, } \\
\text { especially by men } \\
\text { towards women/In the } \\
\text { Middle Ages, chivalry } \\
\text { was the set of rules and } \\
\text { way of behaving which } \\
\text { knights were expected } \\
\text { to follow }\end{array}$ & $\begin{array}{l}\text { impoliteness / } \\
\text { cowardice }\end{array}$ & $\begin{array}{l}\text { fundamental value of } \\
\text { modern men / doing } \\
\text { things the right way / } \\
\text { success tastes better } \\
\text { when shared / code of } \\
\text { conduct that sets them } \\
\text { apart }\end{array}$ & \begin{tabular}{|l|} 
self centred / \\
winning the wrong \\
way or at the cost \\
of others
\end{tabular} & Chivalry \\
\hline $\begin{array}{l}\text { MdDowell's } \\
\text { No.1 }\end{array}$ & $\begin{array}{l}\text { NO.1 } \text { YAARI } \\
\text { (Friendship) }\end{array}$ & \begin{tabular}{|l|} 
affection/ \\
acquaintanceship / \\
alliance / amicability / \\
association/ attachment \\
/ benevolence \\
/harmony company \\
/fellowship/ \\
camaraderie/ \\
companionship
\end{tabular} & $\begin{array}{l}\text { animosity/ enmity/ } \\
\text { disassociation/ hatred/ } \\
\text { hostility / malevolence }\end{array}$ & \begin{tabular}{|l|} 
celebrating the bond of \\
brotherhood / a bond \\
that can be called \\
extended family
\end{tabular} & \begin{tabular}{|l|} 
felling of hatred or \\
malice towards \\
others / self \\
centred and into \\
oneself only
\end{tabular} & $\begin{array}{l}\text { Friendship / close } \\
\text { companion }\end{array}$ \\
\hline
\end{tabular}




\section{Conclusion}

Research proves that purpose and values are elemental to humans. The desire to reach the end state or the higherorder purpose is the innate need of every being which is channelled through decision making. Values are critical motivators of behaviour and attitudes, which in turn help individuals attain their purpose. Values also lead to a positive attitude, which in turn leads to motivations to buy and finally the behaviour stage. Similarly linking yourself, an organization or brand to purpose serves multiple advantages ranging from better financials to committed workforce, equity, longevity, etc. This study shows how this innate need of humans is used by alcohol beverage industry to their advantage. Deviating from the MEC paradigm to sell a product that are undesirable gives a reality check to consumers, of how marketers are using clever advertising to sell their products. How values and purpose are used as tools for engage individuals in their brand.

All this information is valuable from the business viewpoint as it can be used to prepare positioning strategies not only for current products but for new products. Also, this clever marketing of linking product attributes as a means to attaining value state or higherorder purpose is profitable as can be seen Brand Z Top 75 most valuable Indian brands 2019, report. So basically, what can be deduced is that brands are trying to show greater good even by selling a product which itself is harmful. How far advertisers can go down this route of playing around higher-order purpose, however, remains an open question.

\section{References}

1. Alcoholic Beverages - Global Market Outlook (2017-2026). STRATISTICS; 2018. Available from: https://www.strategymrc.com/report/alcoholic-beverages-market.

2. Sheth JN. Marketing Megatrends. Journal of Consumer Marketing. 1983; 5-13.

3. Fabbrizzi S, Marinelli N, Menghini S, Casini L. Why do you drink? A Means-End approach to the motivations of young alcohol consumers. British Food Journal. 2017; 119(8):1854-1869.

4. Reynolds TJ, Gutman J. Laddering Theory, Method, Analysis and Interpretation. Journal of Advertising Research. 1988; 28(1):11-31.

5. Grunert KG, Grunert SC. Measuring subjective meaning structures by the laddering method: Theoretical considerations and methodological problems. International Journal of Research in Marketing. 1995; 12(3):209-225.
6. Gutman J. A Means-End chain Model Based on Consumer Categorization Processes. Journal of Marketing. 1982; 46(2):60-72.

7. Gengler C, Mulvey MS, Oglethorpe JE. A Means-End analysis of mother's infant feeding choices. Journal of Public Policy \& Marketing. 1999; 18(2):172-188.

8. Vriens M, Hofstede FT. Linking attributes, benefits, and consumer values. Marketing Research. 2000; 12(3):4-10.

9. Reynolds TJ, Olson JC. Understanding Consumer Decision Making the Means-End Approach to Marketing and Advertising Strategy. 2001.

10. Vinson D, Scott JE, Lamont LM. The Role of Personal Values in Marketing and Consumer. Journal of Marketing. 1977; 41(2):44-50.

11. De Mooij M. Convergence and divergence in consumer behaviour: implications for global advertising. International Journal of Advertising. 2003; 22(2):183-202.

12. Borden N. The concept of the marketing mix. Journal of Advertising Research. 1964; 2-7.

13. Rokeach M. Beliefs, Attitudes, and Values. 1968; 161.

14. Rokeach M. The Nature of Human Values. Free Press. 1973.

15. Schwartz SH. Universals in the Content and Structure of Values: Theoretical Advances and Empirical Tests in 20 Countries. Advances in Experimental Social Psychology Advances in Experimental Social Psychology. 1992; 25:1-65.

16. Schwartz SH. Les valeurs de base de la personne: Théorie, mesures et applications [Basic human values: Theory, measurement, and applications]. Revue Française de Sociologie. 2006a; 47:249-288.

17. Idoko EC, Ireneus NC, Nkamnebe AD, Okoye VI. Effects of intrinsic and extrinsic product cues on consumers' purchase intention: a study of alcoholic beverage consumers in a developing country metropolitan city. Journal of Arts, Science and Commerce. 2013; 4(3):2.

18. Kardes FR, Cronley ML, Kellaris J, Posavac S. The role of selective information processing in price-quality inference. Journal of Consumer Research. 2004; 31(2):368-374.

19. Olson JC, Reynolds TJ. Understanding consumers cognitive structure: implications for advertising strategy in Percy L, Woodside A. (Eds.), Advertising and consumer. MA: Lexington Books, 1983.

20. Clawson CJ, Vinson DE. Human values - a historical and interdisciplinary analysis. Advances in Consumer Research. 1978; 5:396-402.

21. Rosenberg MJ. In Hovland $C$ and Rosenberg Med. An Analysis of Affective-Cognitive Consistency, in Attitude Organization and Change. New Haven, CT: Yale University Press, 1960.

22. Pitts RE, Woodside AG. Personal value influences on consumer product class and brand preferences. The Journal of Social Psychology; 119:37-53. 
23. Claeys C, Swinnen A, Vanden P. Consumers' Means-End chains for "think" and "feel" products. International Journal of Research in Marketing. 1995; 12(3):193-208.

24. Reynolds TJ, Gutman J. Laddering theory, method, analysis and interpretation in Reynolds TJ \& Olson J C (eds.), Understanding consumer decision making, the Means-End approach to marketing and advertising strategy. Mahwah, NJ: Lawrence Erlbaum Associates Publishers, 2001; 25-62.

25. Davis DE. Integral animal behaviour. New York: Macmillan; 1966.

26. Lehner PN. Handbook of ethological methods. $2^{\text {nd }}$ ed. Cambridge: Cambridge University Press; 1996.

27. Pierce WD, Cheney CD. Behaviour analysis and learning. $3^{\text {rd }}$ ed. New Jersey: Lawrence Erlbaum; 2004.

28. Feather NT. Reactions to equal reward allocations: Effects of situation, gender and values. British Journal of Social Psychology. 1990.

29. Williams RM. Change and stability in values and value systems: a sociological perspective, in Rokeach, M. (Ed.), Understanding Human Values: Individual and Societal. New York, NY: Free Press; 1979.

30. Carman JM. Values and consumption patterns: closed loop, in Hunt, H.K. (Ed.), Advances in Consumer Research, Association for Consumer Research. 1977; 403-7.

31. Ajzen I. Attitudes, Personality, and Behaviour. UK: McGraw-Hill Education; 2005.

32. Bagozzi RP, Warshaw PR. An Examination of the Etiology of the Attitude- Behaviour Relation for Goal-Directed Behaviours. Multivariate Behavioural Research. 1992; 27(4):601-634.

33. Hansen T. Consumer Values, the Theory of Planned Behaviour and Online Grocery Shopping. International Journal of Consumer Studies. 2008; 32(2):128-137.

34. Homer PM, Kahle LR. A structural equation test of the value-attitude-behaviour hierarchy. Journal of Personality and Social Psychology.1988; 54(4):638-46.

35. Shim S, Eastlick MA. The hierarchical influence of personal values on mall shopping attitude and behaviour. Journal of Retailing. 1998; 74:139-52.

36. Frankl V. Man's search for meaning: An introduction to logotherapy. Boston: Beacon, 1959.

37. Krause N. Meaning in life and mortality. The Journals of Gerontology Series B: Psychological Sciences and Social Sciences. 2009; 64(4):517-527.

38. Sone T, Nakaya N, Ohmori K, Shimazu T, Higashiguchi M, Kakizaki M \& Tsuji I. Sense of life worth living (ikigai) and mortality in Japan: Ohsaki Study. Psychosomatic Medicine. 2008; 70(6):709-715.

39. Imperative \& LinkedIn. workforce purpose Index: purpose at work [Internet]. 2016. Available from: https://cdn.imperative.com/media/public/Global_Purpose_Index_2016.pdf
40. Deloitte. The 2016 Deloitte Millennial Survey [Internet]. 2016. Available from: https://www2.deloitte.com/content/ dam/Deloitte/global/Documents/About-Deloitte/gx-millenial-survey-2016-exec-summary.pdf

41. Harvard Business Review Analytic Services and EY. The Business Case for Purpose - A Harvard Business Review Analytic Services Report [Internet]. 2015. Available from: https://www.ey.com/Publication/vwLUAssets/ey-thebusiness-case-for-purpose/\$FILE/ey-the-business-casefor-purpose.pdf

42. Ostler J. Brand Purpose: Leading from the front [Internet]. Kantar Millward Brown. 2019 [cited 29 December 2019]. Available from: http://www.millwardbrown.com/mbglobal/our-thinking/articles-opinion/articles/brandz/ global/2017/brand-purpose-leading-from-the-front

43. Finch JE. The impact of personal consumption values and beliefs on organic food purchase behaviour. Journal of Food Products Marketing. 2005; 11(4):63-76.

44. McDonald R, Wagner T, Minor M. Cheers! A MeansEnd Chain Analysis of College Students' Bar-Choice Motivations. Annals of Leisure Research. 2008; 11(3-4): 386-403.

45. Judica F, Perkins WS. A Means-End Approach to the Market for Sparkling Wines. International Journal of Wine Marketing. 1992; 4(1):10-18.

46. Mahrer AR. Discovery-Oriented Psychotherapy Research: Rationale, Aims, and Methods. American Psychologist. 1988; 43(9):694-702.

47. Mahrer AR and Boulet DB. How to Do Discovery-Oriented Psychotherapy Research. Journal of Clinical Psychology. 1999; 55:1481-1493.

48. Dictionary available from: https:/www.thesaurus.com/ browse $/$ stand $\% 20$ for? $\mathrm{s}=\mathrm{t}$

49. Bibliothèque [Internet]. HEC Paris. 2019 [cited 25 December 2019]. Available from: https://www-statista-com. ezproxy.hec.fr/statistics/946690/india-consumption-shareof-alcoholic-beverages/

50. Bibliothèque [Internet]. HEC Paris. 2019 [cited 25 December 2019]. Available from: https://www-statista-com.ezproxy. hec.fr/statistics/812579/india-market-share-of-spirits-bytype/

51. Bibliothèque [Internet]. HEC Paris. 2019 [cited 25 December 2019]. Available from: https://www-statista-com.ezproxy. hec.fr/statistics/1035004/whiskey-market-share-india-bycompany/

52. Lyons J. Semantics, Vol. 1. Cambridge: Cambridge University Press; 1977.

53. Hurford J, Heasley B. Semantics a Course book. Cambridge: Cambridge University Press; 1983.

54. Leech G. Semantics: The Study of Meaning. $2^{\text {nd }}$ ed. Harmondsworth: Penguin Books; 1981. 
55. Saussure F. Course in General Linguistics. London: Duckworth; 1916.

56. Barthes, R. Mythologies. New York: Hill \& Wang; 1957.

57. Hjelmslev, L. Prolegomena to a Theory of Language. Madison: University of Wisconsin Press; 1961.

58. Chandler D. [Internet]. Visual-memory.co.uk. 2017 [cited 25 December 2019]. Available from: http://visual-memory. co.uk/daniel/Documents/S4B/sem06.html 